\title{
A Study on the Relationship Between Seventh-Grade Students' Self-Regulation Skills and Their Problem-Solving Achievements ${ }^{1}$
}

\author{
Bünyamin Aydın (Corresponding author) \\ Ahmet Kelesoglu Education Faculty, Necmettin Erbakan University, Konya, Turkey \\ E-mail: bunyaminaydin63@hotmail.com
}

Dilek Sezgin Memnun

Faculty of Education, Uludag University, Bursa, Turkey

E-mail: dsmemnun@uludag.edu.tr

\section{Emre Dinç}

School of Education, University of Delaware, Newark, United States

E-mail: edinc@udel.edu

\section{Sevgi Arsuk}

Köroğlu Middle School, Istanbul, Turkey

E-mail:sevgiarsuk@gmail.com

\section{Hilal Meriç}

Fatih Sultan Mehmet Middle School, Istanbul, Turkey

E-mail: meerichilal@gmail.com

Received: March 23, 2019 Accepted: April 21, 2019 Published: April 24, 2019

doi:10.5296/jei.v5i1.14543 URL: https://doi.org/10.5296/jei.v5i1.14543

\footnotetext{
1 This research is a part of the project numbered 161210020 supported by Necmettin Erbakan University in Turkey.
} 


\section{Abstract}

This study aimed to determine the relationship between routine/non-routine problem-solving achievements and self-regulation skills of seventh-grade students who are educated in Turkey. For this purpose, in the 2016-2017 academic year, 133 seventh-grade students who were randomly selected in Denizli and Bursa provinces were studied. In the scope of the study, students were asked to answer routine/non-routine problem-solving tests, prepared by the researchers and the Motivated Strategies for Learning Questionnaire (MSLQ). When the data obtained from the analysis were examined, it was explained that the seventh-grade students attending the study need to develop their routine problem-solving skills and focus more on non-routine problem-solving skill development. Also, it was concluded that there are low-level and positive relationships between students' routine problem-solving and self-regulation skills, and non-routine problem-solving and self-regulation skills.

Keywords: Self-regulation, Self-regulation skills, Mathematical problem, Routine problem, Non-routine problem

\section{Introduction}

\subsection{Introducing the Problem}

The main motive of the living is to survive. For this reason, individuals need to learn how they learn in order to survive. One of the most basic skills that education expects from the individual is to find the most effective way of learning suitable for him/her. In today's society, with an approach that considers individual differences, it is tried to educate individuals who can think creatively and rapidly and learn ways to reach exponentially increasing information (Umay, 2004). Additionally, while some students cannot be successful despite hard work, others can achieve the same success and even be more successful by working for a short period. Therefore, it is crucial for students to know where, how, when and how to use effective learning strategies (Çiltaş, 2011). Studies on the main differences between successful and unsuccessful, productive and inefficient, superior and standard talented individuals also show that students' self-regulation skills and quality/quantity situations in strategy use have an important role in these differences (Sak1z, 2014).

\subsection{Exploring the Importance of the Problem}

Studies on self-regulated learning began in the mid-1980s to find answers to the question: "How can students manage their own learning processes?" (Zimmerman, 2001). These studies have spread over a wide range of concepts in the 90 s and have been conducted from different perspectives: self-regulated learning, self-control, self-management, self-assessment (Boekaerts, Pintrich, \& Zeidner, 2000; Eker, 2014). Self-regulation is a process of self-orientation, where students are transforming their mental abilities into academic skills rather than having a distinct mental ability or academic performance skills (Zimmerman, 1990). Self-regulation is an effective and constructive process in which individuals determine their own learning goals, try to regulate their cognition, motivation, and behavior, and individuals are guided and limited by the contexts and the purposes they have around them (Pintrich, 2000). Kauffman (2004) considers the concept of self-regulation as an effort to 
control and manage the complex learning activities of the individual. Zimmerman (1998) sees self-regulation not as a mental ability like intelligence, but as a process in which an individual can transform his mental abilities into academic achievement. Self-regulation is that the individual observes his/her own behaviors and makes judgments by comparing with his/her own criteria and, if necessary, adapt their behavior to those criteria; in other words, the individual's influence, direction, and control of his/her behaviors. Self-regulation is part of human nature. Therefore, according to Bandura (1977), people's behavior cannot be controlled only by external reinforcements and fines. People organize their behavior on their own (Cited in Senemoğlu, 2005). In addition, the constructivist theory claims that the individual should be the person who constructs the knowledge, and accordingly students form their cognitive structures by constructing their knowledge. From a constructive cognitive perspective, students need to focus on self-regulation skills to regulate their cognitive structures and build new knowledge (Dinç, 2017). Considering all these, self-regulation can be defined as the ability of students to control their own learning process from the stages of planning and goal-setting up to the stage of self-evaluation.

Self-regulatory learners who take responsibility for their own success are more confident and more diligent in acquiring information than passive classmates (Zimmerman, 1990). Even if they are faced with poor working conditions, they can regulate their own learning processes to provide continuous learning and find ways to succeed. Therefore, self-regulation constitutes an important experience in education in terms of developing lifelong learning abilities. In this context, because students have to learn and apply many things necessary for them in life in an informal way, learning how to learn is becoming a necessity. Students who succeed in adopting this method also exhibit a very successful graphic in creative project development (art, literature, inventions, etc.) in the long term (Alc1 \& Altun, 2007; Zimmerman, 2002). Self-regulation helps students to manage their own learning processes and take necessary decisions immediately. It also enables students to be motivated. Therefore, self-regulatory learning strategies should be given importance in order to enable students to explore new learning strategies and develop new strategies (Lee, 2002; Uygun, 2012). In the self-regulatory learning process, students apply cognitive, metacognitive (planning, monitoring, regulation) and behavioral strategies, and motivational elements (self-efficacy, interest) also play an important role in this process (Pintrich, 2004). Self-regulation focuses on the development of students' cognitive, motivational and behavioral strategies. Students who learn and use self-regulation strategies can apply these strategies both in the classroom and outside the classroom (Nota, Soresi, \& Zimmerman, 2004). Cognitive, metacognitive, and motivational strategies play an important role in the control of students' self-learning process. Goal-setting, time management, evaluating self-performance, organizing and transferring, aiming and planning, researching information, observing development, getting help when needed are examples of self-regulatory learning strategies (Zimmerman, 1998).

When the cognitive and metacognitive skills that are effective during the self-regulation process are examined, problem-solving skills are encountered. Problem-solving, which is a complex and subjective process, requires many high-level thinking skills such as understanding, evaluating the problem, gathering the necessary information for the solution, 
proposing different solutions, testing the suitability of these solutions, and finding the most appropriate solution.

When the problem is mentioned, mathematical problems based on four processes come to mind as seen in mathematics textbooks (Heddens \& Speer, 1997). However, the problem has a broader meaning. Most of the thoughts are related to problems. Because thoughts have a purpose, the ways to solve the problem that is engaged in thinking is sought. Considering the ability to think, which is the most distinctive feature of human being, it is seen how problems and problem-solving have a place for the individual. One of the effective ways of thinking and developing the mind is to contribute to the development of the problem-solving skills of the individual because problem-solving is a human mental activity. It can also be explained as "knowing what to do when it is not known what to do" (Altun, 2014). In solving the problem, the thinker has to save the thoughts from certain molds, to think multidimensional thinking and to develop thought structures. Beyond finding a result, it is aimed at finding a way and to get rid of the difficulty (Polya, 1957). Problem-solving, as well as reaching the result, can be described as finding a smart way to solve the problem. The problem-solving process can be explained as doing research with controlled activities in order to reach a goal that is clearly defined but not immediately reached. Therefore, learning to solve a problem is to comprehend the thinking process modeled by that problem.

The most preferred process in problem-solving is a four-stage process by Polya (1887-1985). The stages of this process are: understanding of the problem, the discovery of the strategy related to the solution, implementation of the chosen strategy, and evaluation of the solution. Knowing these steps and working in accordance with them facilitate problem-solving (Altun, 2014). According to Polya, when the problem is encountered, the first thing to be done is to see the end that should be reached. In other words, the problem must be understood in terms of what the problem is waiting from the individual. Then, a plan should be developed by understanding the idea of suitable action. When the plan is set, the application should be started at the right time. Looking at the incomplete solution, which is the most critical educational phase, is the last step of problem-solving. There is a certain process of problem-solving, but there is no specific method. After understanding the systematics of the problem, the individual determines the most appropriate strategy for the problem. It is seen that the most challenging step of the problem is to understand the problem. To understand the problem, it is vital for the individual to express the problem in his/her own interpretation (Polya, 1997). At the next stage, he/she can explain the processes related to the solution of the problem and determine the strategies to be used. According to Polya (1997), the drawback of students not knowing how to solve problems was the lack of ability to maintain thinking processes with a certain channel. He thought that students had misconceptions in the concept of strategy. This indicates that there are common points that self-regulation and problem-solving skills expect from the individual. Therefore, all self-regulation skills of the individual arise in the process of mathematical problem-solving.

Learning mathematics and solving math problems are nested concepts. Different cognitive and affective components can also affect individuals' mathematics learning and mathematical problem-solving. In this study, the effect of self-regulation skills on mathematical 
problem-solving skills was investigated in detail. Teachers have a significant role in the development of individuals, especially primary school students, with self-regulated skills and individuals with high motivational beliefs. Pre-service teachers have problems in the solution of non-routine verbal problems (K1lıç, 2011; Verschaffel, de Corte, \& Borghart, 1997), and it is necessary to investigate the predictive power of self-regulation strategies, which is among the factors that affect problem-solving performance (Kılıç \& Tanrıseven, 2007).

\subsection{Describing Relevant Scholarship}

As a result of reviewing academic literature, many studies conducted have been found about self-regulation skills or mathematical problem-solving skills. There are some recent studies (Garcia, Betts, González-Castro, González-Pienda, \& Rodríguez, 2016; Garcia, Cueli, Rodríguez, Krawec, \& González-Castro, 2015; Kramarski \& Friedman, 2014; Lai, Zhu, Chen, \& Li, 2015; Tzohar-Rozen \& Kramarski, 2014) conducted with elementary school students on self-regulation and mathematical problem-solving addressed together. In the context of this study, which has a sample from Turkey, few studies have been conducted in Turkey at the university level (Alci, Erden, \& Baykal, 2008; Kılıç \& Tanrıseven, 2007) and at the elementary and high school level (Çelik, 2012; Demir \& Budak, 2016; Şimşek, 2012; Totan \& Kabasakal, 2012), which deal with mathematical problem-solving and self-regulation at the same time.

In the study conducted by Kılıç and Tanrıseven (2007), the researchers aimed to examine the power of self-regulation strategies and motivational beliefs of pre-service mathematics teachers to predict non-routine verbal problem-solving. According to the research results, the level of self-regulation strategy use positively affects the level of giving realistic responses to problems. In addition, the level of self-regulation strategy use decreases as the level of unrealistic response increases. The need to develop self-regulating skills has been demonstrated to ensure that prospective teachers approach realistic to non-routine verbal problem solutions. Alc1, Erden, and Baykal (2008) aimed to determine the relationship between the students' mathematics achievements and their perceived problem-solving skills, self-efficacy perceptions, metacognitive self-regulation strategies, and their scores in the university entrance examination, which are indicative of the lessons learned at the university. As a result, it was observed that there was a linear correlation between metacognitive self-regulation strategies and perceived problem-solving skills. It was stated that cognitive self-regulation strategies are an important strategy for self-regulation and that students who are good in these strategies have good academic achievement. It is also underlined that self-regulation strategies are part of the problem-solving process. Çelik (2012) aimed to investigate the relationship between mathematical problem-solving success and metacognitive self-regulation. According to the results of this study in which seventh-grade students participated, a significant relationship was found between mathematical problem-solving success and self-regulation skills. Şimşek (2012), in his study with eighth-grade students with high mathematics achievement, aimed to see the effects of the use of the problem-building technique on their problem-solving skills and to determine their competence in using self-regulated learning strategies. As a result of the analysis, it was determined that these students, who had high mathematics achievement, mostly used 
cognitive self-regulation strategies. In addition, it has been reported that the strategies with the highest frequency of use are elaboration and organization. In another study (Totan \& Kabasakal, 2012), it is emphasized that self-regulation manifests itself as an important element in solving problems encountered in everyday life and in solving more complex and non-routine problems. The aim of the study was to determine the effect of the problem-solving education on students' self-regulation skills. As a result of the research, it was stated that the problem-solving education had a positive effect on the self-regulation skills of the sixth-grade students and the effect was continuous. Demir and Budak (2016), who stated that mathematics was a method used to solve problems in daily life, aimed to investigate the interaction between students' academic achievements in mathematics and self-regulation strategies in their study with fourth-grade students. According to the results of the research, it was found that there was a moderate relationship between students' mathematics achievement and self-regulation skills. In addition, the researchers emphasized that self-regulation and mathematics success were in interaction and indicated that individuals who could control their own learning were successful.

When looking at a large number of students, it is more important for students to control their own learning, in other words, having self-regulating skills. Therefore, knowing the differences in self-regulation skills of the students is very important in determining their educational status and in obtaining the necessary assistance when they need. Accordingly, examining the differences in mathematical problem-solving skills and setting this situation clearly will be of great importance in solving their own self-regulated skill level mathematical problems that they will face in the later stages of their education and in providing the necessary help according to their cognitive status when they receive assistance in case of need.

\subsection{Stating Hypotheses and Their Correspondence to Research Design}

This study aims to investigate the relationship between mathematical routine/non-routine problem-solving achievement and self-regulation skills of seventh-grade students. For this purpose, the following research problems were studied:

1) What are the routine problem-solving successes of seventh-grade students?

2) What are the non-routine problem-solving successes of seventh-grade students?

3) How effective are the seventh graders' self-regulation skills?

4) Is there a significant relationship between the routine problem-solving achievements and self-regulation skills of seventh graders?

5) Is there a significant relationship between non-routine problem-solving achievements and self-regulation skills of seventh graders?

6) Is there a significant relationship between non-routine problem-solving achievements and routine problem-solving achievements of seventh-grade students?

In this study, unlike the studies conducted previously, students' self-regulation and 
routine/non-routine problem-solving skills were investigated together. The study was carried out with seventh-grade students studying in different provinces and was thus more comprehensive, and therefore more valid results were reached. In this context, considering the changes in the Turkish mathematics curriculum and the changes in the place and importance of mathematical problem-solving in textbooks in recent years, the knowledge and success levels and self-regulation skills of seventh graders in routine and non-routine problem-solving have been tried to be revealed.

\section{Methodology}

This part includes information about the participant students, the data collected with the aim of the study, and the statistical analyses.

\subsection{Research Design}

This study was carried out by using a relational screening model in correlation type which is one of the quantitative research methods. Screening models are research approaches that aim to describe a situation that has existed in the past or that exists today. The relational screening model is a research model that aims to determine the presence and/or degree of coexistence between two or more variables. In the relational survey model in the correlation type, whether the variables change together and how the change occurs are examined (Karasar, 1995: 76-86). This research was also conducted through the relational screening model, as the relationship between mathematical routine/non-routine problem-solving achievement and self-regulation skills of seventh-grade students were investigated.

\subsection{Participants}

This study was carried out in the 2016-2017 academic year with 133 seventh-grade students who were randomly selected among the students studying in Bursa and Denizli provinces in Turkey.

\subsection{Data Collection Tools and Data Collection}

Self-regulation and problem-solving studies were examined in the literature, and the Motivated Strategies for Learning Questionnaire (MSLQ), which was developed by Pintrich and de Groot (1990) and adapted to Turkish by Altun and Erden (2006) was applied within the scope of this research. The scale consists of a total of 81 items. It is a scale which is prepared in 7-point Likert type which increases gradually from "not at all true of me" to "very true of me." In the Turkish version, the internal consistency of the whole scale was found to be 0.95 . The scale consists of two dimensions: motivation and learning strategies.

The motivation dimension consists of 31 items, which aim to measure students' goals, value beliefs, beliefs about success in the course and the concerns about the exam, and six sub-dimensions (target orientation, aim-focus, task value, self-efficacy, test anxiety, and control of learning beliefs). The learning strategies dimension consists of 50 items, which measure students' cognitive and meta-cognitive strategies and the use of resource management strategies and nine sub-dimensions (repetition, elaboration, organizing, metacognitive self-regulation, critical thinking, seeking help, learning from friends, etc.) 
(Pintrich et al., 1991). Altun and Erden (2006) calculated the alpha values of the whole scale and each sub-dimension of the scale to determine the internal consistency coefficient of the scale. While the alpha value of the Turkish version of the scale was 0.95 , the alpha coefficient of each sub-dimension of the scale was between 0.67 and 0.91 .

In addition to the MSLQ, Routine/Non-Routine Problem-solving Tests consisting of 10 questions and developed by the researchers were applied in this study. In this context, each problem in Non-Routine Problem-solving Test was prepared to cover a different problem-solving strategy.

\subsection{Data Analysis}

In addition to descriptive analysis, the research data were analyzed through correlation analysis. In this context, firstly, a detailed answer key was prepared by the researchers for analyzing the problem-solving tests, and 0 points for the unanswered question, 1 point for the incomplete answers, and 2 points for the complete answers were given. Then, the total scores of the Routine/Non-Routine Problem-solving Tests were calculated for each student. Then, statistical analyses were made on total scores for each student. At this stage, the scores which can be minimum 0 and maximum 20 are grouped and presented in 4 different categories according to the increase of these scores. As the self-regulation scale was prepared in the Likert type, the evaluation of these scales was scored in such a way as to increase the scores from the negative to the positive, as in the evaluations made for the Likert type scales. After that, the mean scores were calculated by dividing the total number of points taken from each of the items on this scale by the number of items. Statistical analyses were performed on these mean scores. At this stage, in order to interpret the mean scores, the width of the intra-group score ranges was calculated. In this context, the group interval coefficient value was determined by dividing the difference between the largest value in the series of measurement results and the minimum value by the determined number of groups (Kan, 2009: p. 407). Accordingly, in the interpretation of the responses of the participant students to the scale, the evaluation interval was calculated as approximately $(7-1) / 7=0.86$. Intervals for interpreting the responses of participants to this scale were classified and presented as: from "6.22-7.00 fits me" to " $1.00-1.86$ does not fit me." In the evaluation of the correlation results, Pearson correlation coefficient was interpreted: 0.00-0.30 interval as a low-level, 0.31-0.70 interval as a medium-level, and 0.71-1.00 interval as a high-level meaningful relationship (Büyüköztürk, 2010: p.32). In statistical analysis, statistical significance was defined at the .01 and .05 levels.

Spearman and Pearson correlation methods were used to interpret the data. If both variables are assessed on the interval scale, the Pearson correlation value was interpreted; if one of the variables is on the ordinal scale, the Spearman correlation value was interpreted.

\section{Results}

In this section, first, an answer to the research problem, which is "What are the routine problem-solving successes of seventh-grade students?" was sought. In this context, the findings of seventh-grade students' routine (verbal/four operations) problem-solving were 
given in the table below.

Table 1. The findings of seventh-grade students' routine problem-solving

\begin{tabular}{|l|l|l|}
\hline Intervals & $\mathrm{f}$ & $\%$ \\
\hline $0-5$ & 12 & 9.02 \\
\hline $6-10$ & 45 & 33.84 \\
\hline $11-15$ & 43 & 32.33 \\
\hline $16-20$ & 33 & 24.81 \\
\hline Total & 133 & 100.00 \\
\hline
\end{tabular}

The results showed that very few of the seventh-grade students $(9.02 \%)$ received lower scores from the routine problem-solving test. The number of students with $16-20$ points is also limited (24.81\%). In addition, it was observed that the majority of the students $(33.84 \%+$ $32.33 \%=66.17 \%$ ) received scores on the average. This indicates that the majority of seventh-grade students $(9.02 \%+33.84 \%+32.33 \%=75.19 \%)$ had a need for improvement in their routine problem-solving skills.

After this, an answer to the research problem, which is "What are the non-routine problem-solving successes of seventh-grade students?" was sought. In this context, the findings of seventh-grade students' non-routine problem-solving were given in the table below.

Table 2. The findings of seventh-grade students' non-routine problem-solving

\begin{tabular}{|l|l|l|}
\hline Intervals & $\mathrm{f}$ & $\%$ \\
\hline $0-5$ & 40 & 30.08 \\
\hline $6-10$ & 57 & 42.85 \\
\hline $11-15$ & 36 & 27.07 \\
\hline $16-20$ & 0 & 0.00 \\
\hline Total & 133 & 100.00 \\
\hline
\end{tabular}

The findings showed that a significant number of seventh-grade students (30.08\%) received lower scores from non-routine problem-solving tests. There were no students, who received 16-20 points in this test. In addition, it was observed that only a minority of the students $(27.07 \%)$ got 11 or more points. This indicates that non-routine problem-solving skills of all seventh-grade students in the study need to be improved. 


\section{Macrothink}

Then, an answer to the research problem, which is "How effective are the seventh graders' self-regulation skills?" was sought. In this context, the findings of seventh-grade students' self-regulation skills were given in the table below.

Table 3. The findings of seventh-grade students' self-regulation skills

\begin{tabular}{|l|l|l|}
\hline Intervals & $\mathrm{f}$ & $\%$ \\
\hline $1.00-1.86$ & 3 & 2.26 \\
\hline $1.87-2.73$ & 10 & 7.52 \\
\hline $2.74-3.60$ & 19 & 14.29 \\
\hline $3.61-4.47$ & 42 & 31.58 \\
\hline $4.48-5.34$ & 28 & 21.05 \\
\hline $5.35-6.21$ & 29 & 21.80 \\
\hline $6.22-7.00$ & 2 & 1.50 \\
\hline Total & 133 & 100.00 \\
\hline
\end{tabular}

The number of students with positive and high levels of self-regulation skills among the seventh-grade students participating in the study was quite low $(21.80 \%+1.50 \%=23.3 \%)$. This indicates that the self-regulation skills of seventh-grade students participating in the study need to be improved.

In this section, an answer to the research problem, which is "Is there a significant relationship between the routine problem-solving achievements and self-regulation skills of seventh graders?" was sought. In this context, the result of the correlation analysis conducted with the aim of revealing the relationship between the self-regulation skills of the seventh-grade students and the routine problem-solving achievements is given in the table below.

Table 4. The relationship between the self-regulation skills of the seventh-grade students and the routine problem-solving achievements

\begin{tabular}{|l|l|}
\hline Pearson Correlation & Self-regulation Skills \\
\hline Routine Problem-solving Success & $0.081^{*}$ \\
\hline Spearman Correlation & Self-regulation Skills \\
\hline Routine Problem-solving Success & $0.106^{*}$ \\
\hline
\end{tabular}

Note. $* \mathrm{p}<0.05$ 


\section{Macrothink}

A very low and positive relationship was found between routine problem-solving scores and self-regulation skills scores of the seventh-grade students participating in the study. This suggests that the success of routine problem-solving is affected by self-regulation skills.

Then, an answer to the research problem, which is "Is there a significant relationship between non-routine problem-solving achievements and self-regulation skills of seventh graders?" was sought. In this context, the result of the correlation analysis conducted with the aim of revealing the relationship between the self-regulation skills of the seventh-grade students and the non-routine problem-solving achievements is given in the table below.

Table 5. The relationship between the self-regulation skills of the seventh-grade students and the non-routine problem-solving achievements

\begin{tabular}{|l|l|}
\hline Pearson Correlation & Self-regulation Skills \\
\hline Non-Routine Problem-solving Success & $0.270^{*}$ \\
\hline Spearman Correlation & Self-regulation Skills \\
\hline Non-Routine Problem-solving Success & $0.276^{*}$ \\
\hline
\end{tabular}

Note. ${ }^{*} \mathrm{p}<0.01$.

From the obtained data, a low and positive relationship was found between non-routine problem-solving scores and self-regulation skills scores of the seventh-grade students. This suggests that non-routine problem-solving success is positively influenced by self-regulation skills.

In this section, an answer to the research problem, which is "Is there a significant relationship between non-routine problem-solving achievements and routine problem-solving achievements of seventh-grade students?" was sought. In this context, the result of the correlation analysis conducted with the aim of revealing the relationship between routine and non-routine problem-solving achievements of the seventh-grade students is given in the table below.

Table 6 . The relationship between routine and non-routine problem-solving achievements

\begin{tabular}{|l|l|}
\hline Pearson Correlation & Non-Routine Problem-solving Success \\
\hline Routine Problem-solving Success & $0.670^{*}$ \\
\hline Spearman Correlation & Non-Routine Problem-solving Success \\
\hline Routine Problem-solving Success & $0.670^{*}$ \\
\hline
\end{tabular}

Note. ${ }^{*} \mathrm{p}<0.01$. 
The analysis of the obtained data showed that there was a moderate and positive level of relationship between the routine and non-routine problem-solving scores of the seventh-grade students. This suggests that routine problem-solving success has a positive correlation with non-routine problem-solving success.

\section{Discussion}

The results of the analysis in this study showed that routine and especially non-routine problem-solving skills of seventh-grade students in the study need to be improved. Although there is a small number of students who have positive and high-level self-regulation skills from seventh-grade students, the findings showed that the self-regulation skills of these students were in need of improvement. This result supports the conclusion that there is a need to develop self-regulation skills as a result of the research carried out by Kılıç and Tanrıseven (2007). Moreover, these results are in parallel with the results of Totan and Kabasakal's study (2012) which emphasize the importance of self-regulation in routine and non-routine problem-solving skills. The result of their study that problem-solving skills have a positive and sustained effect on self-regulation skills supports the conclusion of this study that the problem-solving skills of students with low self-regulation skills need to be improved. Besides, very low-level and positive relationships between seventh-grade students' routine problem solving and self-regulation skills suggest that routine problem-solving success and self-regulation skills are related. This result supports the results of the study by Çelik (2012). Both studies reported a significant relationship between mathematical problem-solving achievement and self-regulation skills of seventh-grade students. Şimşek (2012), as a result of the study, found that students who have high mathematics achievement use mostly cognitive self-regulation strategies. When the results are interpreted, it is seen that the effect of mathematical problem-solving success and self-regulation skills on each other is linear and positive. The study of Demir and Budak (2016), which found a moderate relationship between mathematics achievement and self-regulation, also supports the low-level and positive correlation between mathematical problem-solving and self-regulation. Similarly, the low-level and positive relationship between non-routine problem solving and self-regulating skills of the students participating in this research suggests that self-regulation skills positively influence the non-routine problem-solving success. This result coincides with the results of the study by Kılıç and Tanrıseven (2007). As self-regulation skills increase, realistic responses to problems increase. This indicates that development and change in self-regulating skills will affect the problem-solving success and therefore mathematics achievement. Alc1, Erden, and Baykal (2008) also stated that self-regulation strategies are part of the problem-solving process and that students who are good in self-regulation strategies have good academic achievement. Besides, the medium-level positive relationship between the routine and non-routine problem-solving skills of seventh-grade students is also noteworthy. This situation showed that change and development of seventh-grade students in routine problem-solving skills would positively affect non-routine problem-solving success. Altun, Bintaş, Yazgan, and Arslan (2004), who define routine problems as problems encountered in daily life where four processing skills are sufficient, stated that elementary school students should be engaged in routine problems before non-routine problems. The results of this study 
also support the results of the study by Altun et al. (2004). In other words, it is thought that if primary school students work with routine problems first, this will contribute to non-routine problem-solving skills.

As a result of this research, self-regulation skills were found to be important in the selection and application of the most suitable solution for the situation in the process of problem-solving. In this context, determining the level of self-regulation skills in the problem-solving process and providing studies in order to develop these skills can provide a more efficient education environment. Self-regulation and related education approaches (e.g., metacognition) should also be considered in designing learning environments and programs. Goal-setting, planning, and self-monitoring, which are part of the self-regulation process should be considered in designs and teachers should have the skills to follow and direct these processes (Dinç, 2017). Additionally, self-regulation skills and problem-solving can also be investigated in other subjects with similar studies, and it may be appropriate to consider self-regulation skills in the preparation of the curriculum.

\section{References}

Alc1, B., \& Altun, S. (2007). Lise öğrencilerinin matematik dersine yönelik öz-düzenleme ve bilişüstü becerileri, cinsiyete, sınıfa ve alanlara göre farklılaşmakta mıdır? Çukurova Üniversitesi Sosyal Bilimler Enstitüsü Dergisi, 16(1), 33-44.

Alcı, B., Erden, M., \& Baykal, A. (2008). Üniversite öğrencilerinin matematik başarıları ile algıladıkları problem çözme becerileri, özyeterlik algıları, bilişüstü öz-düzenleme stratejileri ve ÖSS sayısal puanları arasındaki açıklayıcı ve yordayıcı ilişkiler örüntüsü. Boğaziçi Üniversitesi Eğitim Dergisi, 25(2), 53-68.

Altun, M. (2014). Eğitim fakülteleri ve matematik öğretmenleri için liselerde matematik ögretimi. Bursa: Aktüel Publisher.

Altun, M., Bintaş, J., Yazgan, Y., \& Arslan, C. (2004). İlköğretim çă̆ındaki çocuklarda problem çözme gelişiminin incelenmesi. Uludağ Üniversitesi, Bilimsel Araştırma Projeleri Komisyon Başkanlığı. Proje No: AFP 2001/37.

Altun, S., \& Erden, M. (2006). Öğrenmede motive edici stratejiler ölçeğinin geçerlik ve güvenirlik çalışması. Yeditepe Üniversitesi Edu7, 2(1), 1-16.

Boekaerts, M., Pintrich, P. R., \& Zeidner, M. (2000). Handbook of self regulation. San Diego: Academic Press. https://doi.org/10.1016/B978-012109890-2/50030-5

Büyüköztürk, Ş. (2010). Sosyal bilimler için veri analizi el kitabı. Ankara: Pegem Publisher.

Çelik, E. (2012). Matematik Problemi Çözme Başarısı ile Üstbilişsel Özdüzenleme, Matematik Özyeterlik ve Özdeğerlendirme Kararlarının Doğruluğu Arasındaki İlişkinin Incelenmesi (Unpublished Doctoral Dissertation, Marmara University, Institute of Educational Sciences, Istanbul, Turkey).

Çiltaş, A. (2011). Eğitimde öz-düzenleme öğretiminin önemi üzerine bir çalışma. Mehmet Akif Ersoy Üniversitesi Sosyal Bilimler Enstitüsü Dergisi, 3(5), 1-11. 
Demir, M. K., \& Budak, H. (2016). İlkokul dördüncü sınıf öğrencilerinin öz-düzenleme, motivasyon, biliş üstü becerileri ile matematik dersi başarılarının arasındaki ilişki. Dokuz Eylül Üniversitesi Buca Eğitim Fakültesi Dergisi, 41, 30-41.

Dinc, E. (2017). Differentiated learning environment - A classroom for quadratic equation, function, and graphs. In D. G. Sampson, J. M. Spector, D. Ifenthaler, \& P. Isaias (Eds.), CELDA 2017 Cognition and Exploratory Learning in Digital Age (pp. 237-240). Algarve, Portugal: International Association for Development of the Information Society.

Eker, C. (2014). The effect of teaching practice conducted by using metacognition strategies on students' reading comprehension skills. International Online Journal of Educational Sciences, 6(2), 269-280. https://doi.org/10.15345/iojes.2014.02.002

Garcia, T., Betts, L., González-Castro, P., González-Pienda, J. A., \& Rodríguez, C. (2016). On-line assessment of the process involved in math problem-solving in fifth and sixth grade students: Self-regulation and achievement. Revista Latinoamericana de Investigación en Matemática Educativa, 19(2), 165-186. https://doi.org/10.12802/relime.13.1922

Garcia, T., Cueli, M., Rodríguez, C., Krawec, J., \& González-Castro, P. (2015). Metacognitive knowledge and skills in students with deep approach to learning. Evidence from mathematical problem solving. Revista de Psicodidáctica, 20(2), 209-226. https://doi.org/10.1387/RevPsicodidact.13060

Heddens, J. W., \& Speer, R. W. (1997). Today’s mathematics. New Jersey: Merrill.

Kan, A. (2009). Ölçme sonuçları üzerinde istatistiksel işlemler. In H. Atılgan (Ed.), Eŭitimde ölçme ve değerlendirme (pp. 397-456). Ankara: Anı Publisher.

Kauffman, D. F. (2004). Self-regulated learning in web-based environments: Instructional tools designed to facilitate cognitive strategy use, metacognitive processing and motivational beliefs. Journal of Educational Computing Research, 30, 139-161. https://doi.org/10.2190/ AX2D-Y9VM-V7PX-0TAD

Karasar, N. (2003). Bilimsel araştırma yöntemi. Ankara: Nobel Publisher.

Kılıç, Ç. (2011). İlköğretim matematik öğretmeni adaylarının standart olmayan sözel problemlere verdikleri yanıtlar ve yorumlar. Ahi Evran Üniversitesi Eğitim Fakültesi Dergisi, $12(3), 55-74$.

Kılıç, Ç., \& Tanrıseven, I. (2007). Öz-düzenleme stratejileri ve motivasyonel inançlar ile standart olmayan sözel problem çözme arasındaki ilişkiler. Abant İzzet Baysal Üniversitesi Ĕ̈itim Fakültesi Dergisi, 12(1), 167-180.

Kramarski, B., \& Friedman, S. (2014). Solicited versus unsolicited metacognitive prompts for fostering mathematical problem solving using multimedia. Journal of Educational Computing Research, 50(3), 285-314. https://doi.org/10.2190/EC.50.3.a

Lai, Y., Zhu, X., Chen, Y., \& Li, Y. (2015). Effects of mathematics anxiety and mathematical metacognition on word problem solving in children with and without mathematical learning 
difficulties. PLoS ONE, 10(6), e0130570. https://doi.org/10.1371/journal.pone.0130570

Lee, S. (2002). Gender differences in self-regulated online learning strategies with in Korea's university context. Educational Technology Research and Development, 50(1), 101-109. https://doi.org/10.1007/BF02504967

Nota, L., Soresi, S., \& Zimmerman, B. J. (2004). Self-regulation and academic achievement and resilience: A longitudinal study. International Journal of Educational Research, H41(3H), 198-215. https://doi.org/10.1016/j.ijer.2005.07.001

Pintrich, P. R. (2000). The role of goal orientation in self-regulated learning. In M. Boekaerts, P. R. Pintrich \& M. Zeidner (Eds.), Handbook of Self-regulation (pp. 451-501). San Diego, CA: Academic Press. https://doi.org/10.1016/B978-012109890-2/50043-3

Pintrich, P. R. (2004). A conceptual framework for assessing motivation and self-regulated learning in college students. Educational Psychology Review, 16(4), 385-407. https://doi.org/ 10.1007/s10648-004-0006-X

Pintrich, P. R., \& de Groot, E. V. (1990). Motivational and self-regulated learning components of classroom academic performance. Journal of Educational Psychology, 82(1), 33-40. https://doi.org/10.1037/0022-0663.82.1.33

Pintrich, P. R., Smith, D., Garcia, T., \& McKeachie, W. (1991). A manual for the use of the Motivated Strategies for Learning Questionnaire (MSLQ). The University of Michigan, Ann Arbor, MI.

Polya, G. (1957). How to solve it? New York, NY: Doubleday Company Inc.

Polya, G. (1997). In F. Halatçı (Trans.), Nasıl çözmeli? Istanbul: Sistem Publisher.

Sakız, G. (2014). Öz-düzenleme: Öğrenmeden öğretime öz-düzenleme davranışlarının gelişimi, stratejiler ve öneriler. Ankara: Nobel Publisher.

Senemoğlu, N. (2005). Kuramdan uygulamaya Gelişim, öğrenme ve ögretim. Ankara: Gazi Kitabevi.

Şimșek, A. (2012). Matematik Basarı Duzeyi Yuksek Ogrencilerde Problem Kurma Teknigi Kullanıminin Problem Cozme Basarısına Etkisi ve Ogrencilerin Oz-Duzenleyici Ogrenme Stratejileri (Unpublished Master's Thesis, Akdeniz University, Institute of Social Sciences, Antalya, Turkey).

Totan, T., \& Kabasakal, Z. (2012). Problem çözme becerileri eğitiminin ilköğretim altıncı sınıf öğrencilerinin sosyal ve duygusal öğrenme ihtiyaçları ve becerileri üzerine etkisi. Illkögretim Online, 11(3), 813-828.

Tzohar-Rozen, M., \& Kramarski, B. (2014). Metacognition, motivation and emotions: Contribution of self-regulated learning to solving mathematical problems. Global Education Review, 1(4), 76-95.

Umay, A. (2004). İlköğretim matematik öğretmenleri ve öğretmen adaylarının öğretiminde 
bilişim teknolojilerinin kullanımına ilişkin görüşleri. Hacettepe Üniversitesi Eğitim Fakültesi Dergisi, 26, 176-181.

Uygun, M. (2012). Öz-düzenleme Stratejisi Gelişimi Öğretiminin Yazılı Anlatıma, Yazmaya Yönelik Öz-düzenleme Becerisine, Kalıcılı̆̆a ve Tutuma Etkisi (Unpublished Doctoral Dissertation, Hacettepe University, Institute of Social Sciences, Ankara, Turkey).

Verschaffel, L., de Corte, E., \& Borghart, I. (1997). Pre-service teachers' conceptions and beliefs about the role of real-world knowledge in mathematical modelling of school Word problems. Learning and Instruction, 7(4), 330-359. https://doi.org/10.1016/S0959-4752(97) 00008-X

Zimmerman, B. J. (1990). Self-regulated learning academic achievement: An overview. Educational Psychologist, 25(1), 3-17. https://doi.org/10.1207/s15326985ep2501_2

Zimmerman, B. J. (1998). Academic studying and the development of personal skill: A self-regulatory perspective. Educational Psychologist, 33, 73-86. https://doi.org/10.1080/ 00461520.1998 .9653292

Zimmerman, B. J. (2001). Theories of self-regulated learning and academic achievement: An overview and analysis. In B. J. Zimmerman \& D. H. Schunk (Eds.), Self-regulated learning and academic achievement (pp. 1-37). Newyork, NY: Lawrence Erlbaum Associates. https://doi.org/10.1007/978-1-4612-3618-4_1

Zimmerman, B. J. (2002). Becoming a self-regulated learner: An overview. Theory into Practice, 41(2), 64-70. https://doi.org/10.1207/s15430421tip4102_2

\section{Copyright Disclaimer}

Copyright for this article is retained by the author(s), with first publication rights granted to the journal.

This is an open-access article distributed under the terms and conditions of the Creative Commons Attribution license (http://creativecommons.org/licenses/by/3.0/). 